\title{
Power dynamics in organizational change: an Australian case
}

\author{
Emmanuel Mastio \\ School of Professional Practice and Leadership, \\ University of Technology Sydney, Sydney, Australia, and \\ Kenneth Dovey \\ University of Technology Sydney, Sydney, Australia
}

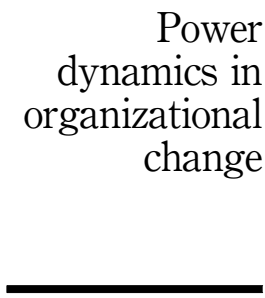

Received 21 July 2019 Revised 29 August 2019 Accepted 30 August 2019 dynamics in change

\begin{abstract}
Purpose - The purpose of this paper is to contribute to the understanding of the role of abstract forms of power in organizational change by exploring the role of such forms of power in the recent structural transformation of an iconic Australian Intellectual Property law firm. The research literature reflects relatively few studies on the increasing complexity of power dynamics in organizational and institutional arrangements. Design/methodology/approach - The complexity of the investigated phenomena led to the adoption of three qualitative methods in order to access the specific forms of data that were perceived to be relevant to answering the research question ("How did abstract power dynamics influence the nature and outcomes of the firm's structural transformation?"). Ethnography was used in the attempt to discern, through participation and observation, the assumptions that manifested in action and/or inaction; phenomenology in the exploration through unstructured interviews with 41 staff members and 4 clients of the firm, of their interpretation and "sense-making" of their "lived experience" of "what was going on" in the firm; and narrative enquiry in establishing a narrative of critical events, and their impact on "what was going on" in the firm, including those that had occurred over the years prior to this research initiative.

Findings - The research shows the effects of contradicting forms of abstract power (namely, hegemonic (ideological) power, dominant institutional logic and structural power) as the firm struggled to address challenges to its existence. The impact of these forms of power upon the partners' apprehension and interpretation of the emerging challenges to the firm's business performance remained inconspicuous throughout the period of transformation. However, these contradictory forms of abstract power insidiously created tensions within the organization which were poorly addressed, resulting in organizational dysfunction and destructive sectarian conflict. The results show that the inability of partners to discern the nature of the forms of power which were influencing their responses to the crisis was a consequence of underdeveloped collectively reflexive capabilities and an absence of collaborative problem-solving practices. This resulted in a negative outcome for the firm.

Research limitations/implications - The research has significant implications for collective endeavor in global business operations that are becoming increasingly complex. In particular, the complexity of power relations, as insidious ideological forces supported by ubiquitous technologies threaten to subsume agentic power in ways that domesticate and neutralize it, requires the development of sophisticated forms of collective ways of "working with power" - capabilities that include the ability to demystify the abstract forms of power that can shape the experience of social realities as "inevitable and natural." Further research into these forms of power, and the surreptitious role they play in organizational arrangements, is an important requirement. With respect to limitations, as the research is located in the interpretivist research paradigm, the issue of interpretation is problematic. A strong effort was made to limit unwitting interpretive bias but the possibility of such bias cannot be ruled out, especially as, in some cases, the data are an interpretation of prior interpretations of events and/or experiences (as, e.g., in the interview data).

Practical implications - Working constructively with various forms of power is becoming a critical capability within organizations. This has implications for the relational and communicative skills that underpin effective collaboration of staff and other stakeholders. Such collaboration needs to include the collective ability to make explicit through critical dialogue the surreptitious influence of abstract forms of power upon the prevailing organizational arrangements and routines. To achieve this, these forms of power have to become demystified through constructive critique of the taken-for-granted aspects of everyday organizational life. This has important implications for leadership development practices and educational programs.

Social implications - Unless leaders develop the ability to make the influences of abstract forms of power more conspicuous, and develop collaborative capabilities to work with insight into their management, they run the risk of agentic power becoming subsumed and neutralized by such forms of power. This has important implications for organizational agency and, especially, for the creative agency of the individuals who work within organizations. On a broader scale, it has implications for institutional arrangements and for the critical apprehension of global ideologies.
\end{abstract}


Originality/value - Studies of abstract forms of power are relatively rare in the research literature. This is probably a result of the long-standing dominance of positivism, with its realist ontological assumptions and its objectivist epistemological assumptions. In exploring the influence exerted by abstract forms of power on the inability of the partners of a professional services firm to apprehend their situation more accurately, and to interpret their strategic options with greater insight, this research makes an original contribution to the understanding of the influence of abstract power dynamics in organizational change, and in organizational arrangements more generally.

Keywords Social innovation, Professions, Organizational skills, Social change, Social dynamics

Paper type Research paper

\section{Introduction}

This paper reports on research conducted into the power dynamics that manifested within an Australian intellectual property law firm (hereafter referred to as IPL) as it faced significant challenges to its business model, professional practices and partnership structure. IPL was not unique in facing such challenges as professional service firms (PSFs) generally are under pressure to adopt alternate forms of logic (such as managerial and market logics) in response to globalization, digitization, ideological shifts (neoliberalism) and the continuous emergence of disruptive technologies (Saks and Muzio, 2018; Olakivi and Niska, 2017; Lander et al., 2017). Professional logic (as traditionally enacted) centers on client relationships, autonomy, collegiality and professional ethics (Leicht, 2018). This contrasts strongly with enterprise logic centered on the view of the market as "the locus of human perfection" (Giddens, 1994). As the market is assumed to be the supreme arbiter of knowledge; there is no need for credentialing/ licensing, codes of ethics or other forms of regulation (Leicht, 2018). Attempts by PSFs to adapt to changing circumstances through structural transformation, thus, can result in the layering of alternate logics upon that of professionalism, creating contradictions and tensions (Adler et al., 2008; Seo and Creed, 2002); undermining the expert status of professionals (Schilling et al., 2012); and disregarding traditional notions of professional autonomy (Thomas and Hewitt, 2011).

There are relatively few studies of the role of abstract power dynamics in attempts by PSFs to transform their partnership structure (Cardinale, 2018; Bévort and Suddaby, 2016). This paper aims to address this deficiency by focusing on this aspect of IPL's structural transformation. Adopting three specific research methodologies, all of which rest within the interpretivist research paradigm, the paper explores the impact of abstract power dynamics as IPL staff tried to make sense of their changing circumstances.

The paper contributes to our understanding of how power dynamics shape organizational change. It showcases the failure of IPL partners to fully understand the workings of abstract power in their apprehension and interpretation of the challenges to their organizational arrangements. This analytical flaw limited their awareness of strategic options when confronted by significant threats to the survival of their firm and undermined their ability to address these threats collaboratively.

The paper commences with an overview of the phenomenon of hegemonic power and other forms of abstract power that manifest in organizational arrangements. Thereafter, the research methodology is outlined; a strategic narrative, in which the research results are embedded, is presented; findings are discussed; and the implications of the research are raised.

\section{The phenomenon of hegemonic power}

There is a vast literature on the phenomenon of power (see, e.g., Lukes, 2005; Weber, 1970), coverage of which is beyond the scope of this paper. However, although there is a long history of debate over the nature of power and its apprehension, consensus on the forms through which power manifests remains elusive (Lukes, 2005; Bachrach and Baratz, 1962). In this paper, we focus on the third dimension of power according to Lukes' (2005) 
classification: namely, forms of abstract power where groups acquiesce unwittingly to their own domination (the other two dimensions of Lukes' classification refer to where the exercise and consequences of power are observable and where the power agenda is disguised and controlled in a way that benefits a particular power elite). We commence by exploring hegemonic power and its role in support of a particular social order. As with all forms of abstract power, this form of power shapes peoples' apprehension of the existing social order as an inevitable and natural phenomenon of life (Tilly, 1991, p. 594).

Historically, the modernization project, that exemplifies human endeavor over the past millennium, celebrated the agentic power of heroic individuals who, it was claimed, contributed to the achievement of the project's goal of greater human control over features of the natural reality. More recently, however, the "dark side" of this project - namely, the subsuming of agentic power by various forms of hegemonic power supported by ubiquitous technologies - has been raised (Foucault, 1984; Stanley, 1978; Williams, 1977; Gramsci, 1971). This challenge to traditional conceptions of power was initiated by the writings of neo-Marxists like Gramsci (see 1971) in the early twentieth century which laid the foundations for the emergence of alternative research paradigms through which the notion of "social realities" was introduced. These were viewed as being socially created and sustained not only through the exercising of traditional forms of power which are more easily apprehended (through decisions made, objectively validated actions taken and consequences observed) but also through insidious forms of power that are difficult to discern; a feature upon which their efficacy rests. As Lukes (2005, p. 12) states, this view of power is that of a "capacity" and not necessarily "the exercise of that capacity" in that "it may never be, and never need to be, exercised." In this sense, hegemonic power differs from ideological power in that it manifests through a "whole lived social process" practically framed by specific meanings and values. Ideology, on the other hand, manifests through a formal articulation of a system of meanings, values and beliefs; one that can be abstracted as a worldview.

From this perspective, social realities are political phenomena; inter-subjective in nature and reliant on the influence of hegemonic power for them, and the social order they underpin, to prevail without direct opposition and contestation due to the unwitting internalization of the values, tastes and interests of an unrecognized dominant elite. This form of power manifests surreptitiously, as:

[...] a whole body of practices and expectations, over the whole of living; our senses and assignments of energy, our shaping perceptions of ourselves and our world. It is a lived system of meanings and values - constitutive and constituting - which as they are experienced as practices appear as reciprocally confirming. (Williams, 1977, p. 110)

In this way, the workings of hegemonic power are mystified via a process of reification whereby the political interests that underpin any social reality become invisible, and the agentic power of those whose interests are subsumed and distorted by that reality is domesticated and neutralized (Gramsci, 1971; Berger and Pullberg, 1965). Embedded in everyday practices and vested in dominant discourses (ideological and cultural), this form of power shapes the assumptions, values, routines and arrangements that underpin the experience of the status quo as natural and inevitable; thereby mystifying the interests served by the prevailing social order and secretly disarming agentic power as it surreptitiously shapes the "rules of meaning and membership" (Lawrence et al., 2012, p. 106); rules which extend their reach into the very constitution of an individual's identity (Knights and McCabe, 1999).

The advent of postmodernism in the mid-to-late twentieth Century signaled a growing pessimism regarding the possibility of agentic resistance to hegemonic power. In his conflation of power and knowledge, with knowledge theorized as an institutionalized and controlling system of thought, Foucault (1984) argued that the workings of hegemonic dynamics in

organizational change 
power are not only coercive (and repressive) but also productive, which means that any form of opposition will simply be subsumed by hegemonic discourses. As Cooper and Burrell (1988, p. 94) expressed it, postmodernism posits the politically conservative view that "systems have lives of their own which make them fundamentally independent of human control." This pessimistic assumption of the demise of agentic power coincides with the rise to global dominance of neo-liberalism over the past four-to-five decades; an "ideological turn" that has centralized the power of global elites in mystified systemic forms that increasingly incorporate institutions and organizations (Hanlon et al., 2017; Monbiot, 2016; Whitehead and Crawshaw, 2014; Peck and Tickell, 2002). Furthermore, postmodern theorists have highlighted the role of new technologies in strengthening the influence of hegemonic forms of power; the ubiquity and insidiousness of which is claimed to be further subsuming (and thereby debilitating) agentic power. For example, Jameson (1984, p. 87) sees the ideological underpinnings of corporate capitalism, in association with the growth of information technology, as a system so totalizing that it makes the achievement of "critical distance" impossible, thus disarming any form of opposition to itself, so that:

$[\ldots]$ not only punctual and local countercultural forms of cultural resistance and guerrilla warfare, but also even overtly political interventions [...] are all somehow secretly disarmed and reabsorbed by a system of which they themselves may well be considered a part, since they can achieve no distance from it.

\section{Other forms of abstract power manifestation in organizations}

Other forms of abstract power also manifest in organizational endeavor; forms which are more vulnerable (than hegemonic power) to becoming discernible as they are less insidiously bound to the identity-formation and sense-making processes of everyday life, and because alternative options to them are potentially observable, especially under changing circumstances. These forms of abstract power include an embedded institutional logic and the way organizational arrangements are structured and implicitly justified.

Institutional logic refers to everyday work practices, and the assumptions and systems of meaning that frame these practices, through which sense is made of organizational experience (Thornton et al., 2012). Organizational practices are usually embedded in an institutional field and thus are also influenced surreptitiously by the dominant institutional logic(s) operating within that specific field. As Jepperson (1991, p. 149) points out, institutions are "socially constructed, routine-reproduced programs or rule systems," with the taken-for-granted status of these rule systems being a fundamental attribute of institutionalization. Thus, he argues, power and interests are fundamental to their creation and re-creation but, given their "taken-for-granted" status, "rationalized myths" help to obfuscate the political interests supported by institutions. From this perspective, "the sources of power, its meaning, and its consequences are contingent on higher-order institutional logics" (Thornton and Ocasio, 1999, p. 802).

Structural power refers to organizational arrangements that also, over time, constitute a sense of experienced reality beyond which it is very difficult for embedded participants to think. As the structure and associated practices are reified, alternative forms of everyday arrangements and of problem solving are rendered unimaginable, making organizations vulnerable to exogenous shocks (Seo and Creed, 2002, p. 235). Lawrence et al. (2001, p. 630) concur, arguing that this influence occurs in a "routine and seemingly disinterested way." Furthermore, Soulsby and Clark (2013) view structural power as predetermining the nature of the rules of the political game and as inherently mobilizing its self-sustaining bias. Courpasson (2000, p. 143) goes further in saying that structural power, in conjunction with the institutional logic, serves "to construct, justify and stabilize the obedience of people" without their own awareness thereof. Hardy and Clegg (1999, p. 377) view structural power 
as permeating "the fiber and fabric of everyday life," and the conceptualization of organizations as reflecting and reproducing the organizing principles that underpin the accepted nature of social and economic behavior. In this way, this form of power manifests as the capacity to facilitate and/or constrain action; that is, to ensure conformity to the rules and conventions embedded in the social order. However, Cardinale (2018, p. 133) questions the assumption that structure only constrains (makes some actions impossible) and enables (makes some actions possible). He argues that structure also actively induces actors to pursue some of the possible actions rather than others.

\section{Power fault lines at the organizational level}

Under certain conditions, the influence of insidious forms of power can become visible. As Bertels and Lawrence (2016, p. 338) point out, contradictions can lead to tensions within organizations which, in turn, can open windows of insight into the workings of abstract power. Seo and Creed (2002, p. 226) concur, arguing that contradictions can lead to the emergence of change agents who are able to disrupt the prevailing "mutually reinforcing systems of practices, interests and ideas." Tensions resulting from such contradictions include those generated by the inability of the organization to adapt to changing operational environments; increasing functional inefficiencies as a consequence of attempts to retain legitimacy in ideological contexts that are transforming; and the adoption of practices which contradict the dominant logic of the organization and create incompatibilities within the institutional field (Pache and Santos, 2013; Borum, 2004).

Another important source of intra-organizational tensions occurs in turbulent times when the power interests which the organizational arrangements serve become demystified. Those whose interests are not adequately served by the prevailing arrangements become potential disruptors of the organizational order if economic and other forms of crisis enable the "rationalized myths" of the political order to become more discernible and, thus, contestable (Jepperson, 1991). Furthermore, tensions between individual and collective interests are likely to be activated by such exogenous "shocks," leading to a critical number of actors collectively deciding to contest the organizational arrangements (Barley and Tolbert, 1997).

\section{Possibilities for agentic action}

Bertels and Lawrence (2016, p. 338) argue that individuals have complex relationships with the logics that dominate organizational endeavor; relationships that go beyond their organizational roles and which are strongly influenced by their individual and professional identities. The introduction of competing logics exacerbates this complexity. Where subgroup identities form and are affiliated to competing logics, this can "exacerbate tensions between logics, thereby making their combination untenable" (Battilana and Dorado, 2010, p. 1420).

Identities are a product of individual and group biographies. These are constructed through lived experience and the narratives of meaning that individuals/groups adopt or create in making sense of their experience. However, identities are contingent upon the nature of the social order in which individual lives are embedded and, thus, they are political in nature as, "neither change agents nor their identity targets can operate outside the power relations through which their identities exist and are acquired, claimed, and allocated" (Lok, 2010, p. 1307). Thus, for change agents to emerge there needs to be some disruptive event(s) in their personal and/or professional biography; a "crisis" that demystifies the nature of the social order (and the narratives of meaning it promotes) in which the individual is embedded.

Organizational transformation, however, requires collective action, and this depends upon collaborative capabilities. In this respect, Benson (1977) advocates praxis as a change methodology that can deliver an insightful critique of existing arrangements; the identification of viable alternatives; and the mobilization of action. Seo and Creed (2002, p. 223) concur, arguing that praxis may be a core practice for the reconciliation of two seemingly incompatible 
phenomena: embeddedness and transformational agency; and that adopting a dialectical framework may also alert us to the ways in which the construction and re-construction of social realities is an outcome of political struggle among multiple social constituencies with unequal power. At the core of such "political action" is the collective ability to "work constructively with" diverse forms of power (Clegg et al., 2006). Change, in its deep form, is a complex undertaking; requiring what Freire (1974) called processes of concientization whereby inculcated assumptions, dominant interests, the discourses of power, "rationalized myths," etc., are critically scrutinized through meaningful collective debate on contested positions. While critical social theorists view such reflexive practices as capable of demystifying hegemonic and other forms of abstract power (Cunliffe, 2009), generally such practices are viewed as "subversive" in organizations, and their development resisted (Hanlon et al., 2017; Schostak, 2016; Kezar, 2011; Morrill et al., 2003).

This review of the literature on the power dynamics of organizational arrangements and their implications for transformative action leads to the research question:

$R Q 1$. How did abstract power dynamics influence the nature and outcomes of IPL's structural transformation?

\section{Research methodology}

In seeking to understand "what was going on" with respect to power dynamics within IPL in its attempts to address challenges to its existence, this research responds to the call by Suddaby et al. (2008) for more investigations of PSFs from "within." By locating the research in the interpretivist research paradigm, the research setting was viewed as a socially constructed reality in which a recursive relationship manifested between institutionalized assumptions regarding "how the world works" (ideology); structurally embedded shared assumptions (culture), and personal assumptions generated through individuals' "lived experience" of that social reality (mental models).

The researchers' epistemological assumption was that the knowledge sought through the research process is subjective and inter-subjective in nature, as well as being embedded in the rituals, routines and artifacts of everyday life within the research settings. The complexity of the investigated phenomena led to the adoption of three qualitative methods in order to access the specific forms of data that were perceived to be relevant to answering the research question. Ethnography was used in the attempt to discern, through participation and observation, the assumptions that manifested in action and/or inaction; phenomenology in the exploration through unstructured interviews with forty-one staff members and four clients of the firm, of their interpretation and "sense-making" of their "lived experience" of the firm's attempts to address the significant challenges it faced; and narrative enquiry in establishing a narrative of critical events, and their impact on "what was going on" in the firm, including those that had occurred over the years prior to this research initiative. The results of the study are presented as a narrative based on data sources that include multiple interviews with the Chairman of the Board; interviews with 41 staff members and 4 major clients; notes based upon participant-observation over a two-year period; various forms of internal documentation such as executive board reports; an external consultant's report; press releases; and regulatory policy announcements.

The research occurred over a period of two years. The firm agreed to the first author spending considerable time each week in the firm's Sydney office; attending board meetings and internal presentations; and having access to staff for interview in each of the four regional offices, as well as to four of IPL's long-term clients. With assistance from the Chairman of the Board (called XY in this paper) a narrative of critical events within the firm over the previous 20 years was developed. The information conveyed through this narrative is supported/ corroborated at relevant points by drawing on the broad range of data outlined above. 
Interviews were conducted with staff, randomly selected from each positional category (equity partners down to support personnel) based in Sydney, Melbourne, Brisbane and Perth and ranged in duration from 30-45 min. The questions were open-ended and were followed up with a series of probes that sought to gain more detailed explication of the interviewees' interpretation and sense-making of their experience of "what was going on" at IPL. Through these probes (requests such as "can you elaborate please?", "why do you think that happened?", "what initiated that event?"), the interviewer (one of the authors of this paper) sought as far as possible to make explicit the insights gained from the experience, as well as the meanings ascribed to them, by those interviewed. Thus, through the relational dynamics of generative conversation, the interviewer attempted to gain access to interviewees' experientially privileged knowledge of the processes, practices and events occurring at IPL. However, as a participant in the conversations, the interviewer became a co-producer of the meanings ascribed by those interviewed to the experience. As Carroll and Simpson (2012, p. 1287) argue, "there is no stable external 'spectator' viewpoint; rather all actors, including researchers, are co-evolving participants in the construction of relationships, structures, realities and meanings." This can be construed as a limitation of the methodology.

Each interview was transcribed and shared with the interviewee for confirmation of the accuracy and the anonymization of content. Thereafter, the interview data were analyzed individually, and the results compared by the authors in an attempt to limit individual bias in the analysis. Goffman's (1974) notion of "frames" was used as a form of interpretive scaffolding in the engagement with the explicated perspectives of those interviewed, recognizing that such frames mediate the "meaning-making" embedded in conversations by evoking shared meanings that serve as an interpretive context (Mead, 1934).

\section{The case: the structural transformation of IPL}

IPL has existed for over 100 years. Structured from its beginning as a professional partnership, there has until recently been "a fusion of ownership and control, revolving managerial tasks among owners, consensus-based governance, a high degree of professional autonomy, collegiality, and minimal management structures and systems" (Lawrence et al., 2012, p. 104). By 2016, IPL had 33 partners, 19 of whom were equity partners, operating on the "lock-step" model whereby profits were pooled and shared among equity partners based on the number of equity units each held (equity units being based on an individual's length of service). The Sydney and Melbourne offices are significantly larger than the offices in Perth and Brisbane.

Three dominant themes emerged from the interviews with IPL staff and customers. For a theme to be considered dominant it had to occur in more than 50 percent of the staff interviews (i.e. raised by more than 20 of the staff interviewed) and in 75 percent of client interviews (i.e. raised in at least three of the four client interviews). All three themes reflect the conflict, and consequent tensions, between the four IPL office locations (especially between the Sydney and Melbourne offices) over whether the partnership structure of the organization should be retained (favored by the majority of the Melbourne office) or be transformed into a corporate structure (favored by a majority in the Sydney office). Those in favor of decoupling the ownership from the management of the organization viewed such a transformation as essential to the installation of standard processes to which everyone, irrespective of rank or station, would be forced to conform in order to address effectively the business challenges that the organization was encountering.

Second, there was conflict over whether the costs of production should be reduced and processes refined through automation, off-shoring and the streamlining of back-office systems given the various factors (technology, globalization, cheaper offshore locations, the introduction of platform economics, changing attitudes to IP protection (especially in the USA), the licensing of IP to large companies who use in-house attorneys to file and prosecute patents, IP attorneys' knowledge becoming commoditized (through automation), etc.) that 
some staff argued to have lowered margins dramatically and disrupted the traditional work of IP firms. Customers, especially, were critical of IPL's back-office systems.

Third, the interviews reflected debate over whether IPL had the professional capabilities to compete through the offering of higher-level business consulting services. Most in the Melbourne office believed that IPL attorneys were capable of delivering such services to clients, with the problem being IPL had failed to establish contact points with clients at Board/CFO level as opposed to research and development (R\&D) level). Many in the Sydney office, however, believed that the knowledge-base and mind-set of IPL's patent attorneys was too narrow, and that they lacked the collaborative skills required to explore the clients' business context in order to offer sage strategic advice. On this issue, customers concurred with the view that IPL needed to re-think the nature of its workforce in order to offer competitive high-level services in the market.

Data gained from each of the three research methodologies are embedded at appropriate points in the strategic narrative that outlines IPL's transformation journey.

\section{The strategic narrative of the structural transformation}

One support staff member expressed well the competitive context of IPL historically:

It's probably been only 15 years, maybe a bit more, that they've competed for work [...] it's been a very sheltered industry.

This bred complacency, as articulated by an equity partner:

You become complacent and believe that the work is going to roll in the way it always has [...] an incoherency (develops) between how we perceive the business and how the market sees us.

The first signs of disruption in the late 1990s were flat growth and having to discount pricing in the marketplace. However, operational inefficiencies continued to be tolerated, as one support staff member complained:

We've got 33 partners. Every one of those people have their own way of doing things, which makes it incredibly hard for us to scale our service offerings. The fact that we do not have standard processes in place is a fundamental impediment.

Similarly, clients were frustrated with the inefficient back-office functions of the firm:

I don't like the patent renewals process [...] it is very annoying! Another of the painful things is their invoicing system. Their backroom functions need to be more efficient.

There's an obvious inefficiency issue. They need to fix up their back-office functions.

The temporary boost in revenue created by the dot-com phenomenon allayed concerns about business performance. However, with the dot-com collapse, performance issues re-emerged, and a general manager was appointed in 2001 to assist the business to operate in a more structured way. His brief was to manage the partners: a toothless role given the power inequalities between him and them. This was followed by the appointment of a CEO in January 2006, who also failed to change partner behavior.

In February 2007, XY, a senior equity partner based in the Sydney office, joined the National Management Committee of IPL and became an advocate for change in the way the firm operated. In April 2008, he was instrumental in bringing in an external consultant to review the firm's operations. As he comments:

We were trying to be more structured in the way we ran the business - most of the partners had been a patent attorney forever and needed organizational skills. The big challenge we faced was the inability to act on issues. A whole lot of subcommittees were set up which never delivered anything. It really was just an aggregation of practices. 
The consultant's report highlighted the dysfunctionality of the partnership structure and recommended the transitioning to a corporate structure. XY explains the Board's response:

The Board decided to promote the recommended change to the partners on the basis that the new structure would free up time for them to concentrate on their practice. The carrot was for the equity partners to view this change as making the business more profitable.

Many partners dismissed the validity of the consultant's research and recommendations. The recommended changes were introduced but most partners continued to operate as usual, as XY explains:

To get rid of someone, you had to have a unanimous vote except for the person who you were trying to expel from the partnership. Thus, everyone only needed one friend. The constitution of the partnership made it very difficult to hold any principals to account except through persuasion.

In August 2008, the global financial crisis produced an exogenous "shock" for the IP profession. As XY recounts:

Overseas companies culled their filing portfolio, and investment in IP into Australia dropped off internationally. There was also a tightening within the Australian market.

However, IPL continued to emphasize its strategic commitment to the local market which generated around 40 percent of its annual revenue. As XY explains:

We wanted to position ourselves to work primarily for domestic clients. Our fear was the potential harmonization of international patent laws that would allow the filing of a single patent that gives protection in multiple jurisdictions. Furthermore, new entrants were coming in with online platforms to take the high margin work.

As one of the support staff commented, this sparked indignation among IPL partners:

There was outrage at the idea of intermediary online platforms cutting out that profitable filing end of the process. There was a genuine, "How dare they come into this space?" which reveals the high level of insularity in thinking.

The Board's response was not to counter this intrusion with a similar platform strategy, as explained by a senior equity partner:

An important factor was that a lot of our work depended upon the network we have in overseas jurisdictions. These platforms were held in poor regard by them, so we feared that this would disrupt these long-standing relationships. We didn't want to be seen to be part of the insurgent crowd; we wanted to be seen to be part of the establishment.

Changes in the market, however, included the increasing threat of IP attorneys' knowledge becoming commoditized through new technologies, as recognized by a senior equity partner:

The part of the business where we've been generating our revenue is becoming commoditized.

In January 2009, the National Management Committee was replaced by a Board, as recommended in the consultant's report. In January 2010, a new CEO was appointed and, teaming up with the CFO, he commenced negotiations with the partners on the transformation to a corporate structure. The Board's role was limited to recommendation of the process; thinking about the strategy through which it could happen; and exercising whatever influence they had with the partners. Although there were tensions among Board members too, escalating dysfunction within the firm led to them considering the opportunity to discontinue the partnership structure by selling the firm to a listed company. To sell the business (in order to restructure it) at least 75 percent of the equity partners had to vote in favor. At this point, though, only around 50 percent were open to considering the change. dynamics in organizational change

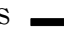


One of the factors that strengthened the resistance to the change was a spate of retirements of senior partners, and the admission to the partnership of several relatively young attorneys. As XY complained:

New young partners formed a coalition that was very reactionary. They were more conservative than some of the partners who were exiting but who had had more integrity around what it was to be a partner - about the issues around stewardship and leaving the firm in a better place than when you got there.

$\mathrm{XY}$ continued his attempts to get the equity partners to agree to broadening IPL's offerings. In 2007-2008, a law practice had been introduced and, in 2011, an R\&D tax consulting service was included in IPL's offerings. In 2013, XY became Chairman of the Board. That same year, new legislation in the USA (the America Invents Act) resulted in a spike of filings from that country. Soon thereafter new legislation in Australia (the Raising the Bar Act) was introduced which resulted in a spike in filings from local companies as, when new legislation is introduced, there is a period of advantage to being under the old legislation as XY explained:

People brought forward their work, which had a flow-on effect of all the normal prosecution. It inflated the profits and there was a pull-through from that.

This boost in profits placated the partners and reduced the pressure on the business to change. However, the Board, led by XY, continued to explore options to broaden the offerings of IPL with government grant advice, IP economics and a digital platform being introduced.

In October 2014, XY commenced discussions with an international IP firm that operated out of the UK, with respect to forming an association with them as a stepping stone into the Asian market, as he explained:

I began engaging with an international law firm specializing in IP that had a good practice in Asia that didn't include patent drafting. I felt that an alliance with them would provide us a pipeline into Asia, but most partners would not even consider it.

Attempts to initiate strategies like this were strongly resisted by the coalition of new young partners, as XY explained:

Later we wanted to open an office in Singapore. The coalition of young partners came up with millions of reasons why we can't do it rather than a proper exploration of the opportunity. Their reasons always seemed to be driven by personal interests.

In December 2014, an endogenous "shock" impacted IPL where the perceived lack of empathy from some partners toward one senior partner who had been seriously ill polarized the group. In circumstances where a partner cannot work for six months, there was a contractual obligation for him/her to re-apply for appointment. In this case, the necessary percentage of partners voting to accept his application for (re)appointment was not attained and the application failed. This decision shocked some partners, creating among them a sense of the demise of ethical and professional principles within the firm.

In December 2015, the Board endorsed XY's proposal to commence discussions with the CEO of a listed IP law company, called WXY hereafter, with respect to the selling of IPL to this listed company. This strategy had been used by other Australian IP law firms who had sold out to a listed company as a way of transforming the partnership structure to a corporate structure. In November 2016, XY called for a vote on dissolving the partnership and selling the firm to WXY. The 75 percent majority vote was attained on the basis that the equity partners would be paid out the value of their equity (50 percent in cash and 50 percent in shares held in escrow for two years). In February 2017, the deal was completed, and IPL was sold to WXY with a six-month "earn-out" strategy for partners. 


\section{Discussion}

The strategic narrative of the case reflects organization tensions created by the contradictions between ideological changes, institutional logics and the partnership structure of IPL. While broader (global ideological) forms of abstract power appear to have influenced XY and his small group of supporters to advocate for IPL's adoption of a corporate structure with its associated managerial logic and practices, those partners who were resisting change appeared still to be under the influence of the dominant (institutional) logic of professionalism and the arrangements of the traditional partnership structure. This orientation led to their resistance to any alternative structural arrangement and, thereby, to any change to their professional practices (and, thus, identity). Even in the face of recurring poor business results, the influence of the dominant logic of professional practice was evident, with these partners advocating the strategy of everyone "just working harder" as the solution to IPL's poor economic performance, as one equity partner's criticism of XY demonstrates:

He should just put his head down and meet his budget instead of wasting his time thinking about the business. If everyone made budget, we wouldn't have a problem.

A question that arises is why hegemonic power was the stronger influence upon the orientation of XY and his supporters? All had many years of experience in the profession and had, in the past, uncritically conformed to the dominant institutional logic and the dictates of the partnership structure. One explanation is that this orientation was initiated by the tensions created by the contradictions that began to manifest as the operational environment transformed in line with global ideological pressures (Pache and Santos, 2013; Borum, 2004; Barley and Tolbert, 1997). As Seo and Creed (2002, p. 226) argue, contradictions can lead to the emergence of change agents who are able to discern the prevailing "mutually reinforcing systems of practices, interests and ideas," and the relationship between these systems and the economic performance of the organization. In this case, the contradictions began to manifest through declining business results. As IPL failed to address performance issues in a transforming global ideological context, the growing business need for functional efficiency and for the introduction of new high-level consulting services, contradicted the desire for institutional legitimacy. Further contradictions emerged from IPL's inadequate organizational responses to disruptive events and technologies, and from its attempts to install managerial practices. Perceived by most equity partners as an affront to their professional identity, the introduction of managerial logic exacerbated the underlying tensions within the firm. In this way, the formation of two subgroup identities, which were affiliated to competing logics, exacerbated tensions between these logics "making their combination untenable" (Battilana and Dorado, 2010, p. 1420). These contradictions confused identities and changed the "rules for meaning and membership" (Lawrence et al., 2012, p. 106), enabling the disruption of taken-for-granted working arrangements and, thereby, creating the conditions for the demystification of the "rationalized myths" upon which the organizational order was founded (Jepperson, 1991).

While the tensions introduced by contradictions appear to have contributed to the emergence of $\mathrm{XY}$ as a change agent, his personal biography seems to have played an important role too. XY's more international orientation differentiated him from the other partners. The origins of this broader perspective emerged when XY shared a personal story with the paper's authors; a story that supports the point made by Lawrence et al. (2001) that, at the micro-level, biographies may mediate the relationship between individuals and the dominant organizational/institutional logics. The story reflected XY's strong sense of obligation to serve Australia; an orientation that appeared to be motivated by his "personal" biography (his father had received the Order of Australia award for extraordinary service to Australia). XY's commitment to enabling IPL to become a successful global organization dynamics in organizational change 
reflected the influence of hegemonic power in terms of his nationalism; a disposition that brings to mind Lok's (2010) comment about change agents being bound by the power relations through which their identities are acquired and developed. Although a passive person by nature, this biographical heritage motivated XY to sustain the political action which he viewed as pertinent to the saving of an iconic Australian firm, in addition to upholding the norms and principles of professionalism. Herein, however, lies another contradiction in that XY appeared to be unaware of any incompatibility between professional logic and that of managerialism. Similarly, the group of partners who had resisted XY's attempts to restructure IPL into a corporate entity, and who had championed IPL's partnership structure and professional practices, ironically, in the end, were content to sacrifice espoused professional values and principles in favor of financial outcomes (as evident in their ultimate abdication of responsibility for the survival of the partnership in favor of individual financial payments). These contradictions appear to endorse the point made by Lawrence et al. (2012, p. 106) that, under such circumstances, identities become confused as the "rules for meaning and membership" change. With respect to the research question, the contesting abstract power dynamics made divergent interests among partners more apparent and created identity and strategic confusion across the entire body of partners, leading to organizational dysfunction and interpersonal acrimony.

The case reflects how regulatory changes can lead to unexpected outcomes in that the America Invents Act and the Australian Raising the Bar Act ironically further strengthened the position of the resisting partners by creating a (temporary) increase in filings that were brought forward to be prosecuted under the old laws. The "intermittent rewards" experienced in this way, reinforced the resisting partners' commitment to the status quo allowing the proverbial "elephant in the room," namely, the dramatic ideological and technological changes in IPL's operational environment, to go unnoticed (or disregarded) by them.

In terms of the manifestation of power dynamics at the micro-level, the case demonstrates the limitations imposed by hegemonic power dynamics upon the partners' comprehension of situations and strategic options. With respect to the research question, the narrative reflects a haphazard process, as XY conceded in a post-transformation interview:

How would I do it differently? Firstly, there was no formal change management program in place. Secondly, we needed to be a lot clearer about what we were going into rather than what we were coming out of. There was absolute naivety around the impact of the change.

This "naivety" was mostly a consequence of poor comprehension of the abstract power dynamics that were influencing IPL's situation. Most partners had been practising IP attorneys "forever" (as XY expressed it) resulting in their worldview being shaped surreptitiously by the taken-for-granted practices embedded within the professional partnership structure. Each attorney operated as an independent entity in an operational context where, historically, their advice was uncritically accepted by their clients. However, as the business environment of clients transformed, the self-interested assumptions and practices of IP attorneys came under question, as one client expressed:

The attorneys err in assuming they're right and you're wrong. For example, they had this idea of offering strategic advice. That whole thing was written for (IPL) and not for the customer.

Similarly, the practice of patent drafting did not encourage collaboration between individual attorneys. Each attorney costed the drafting process and billed clients independently, and in most cases prioritized "making" his/her budget ahead of transferring work to other partners who may have been more knowledgeable in that area. As one equity partner expressed it:

Attorneys' primary goal is to make budget. They don't get rewarded for referring work to other departments or even for keeping the client happy. There's no formal process of recognizing good work other than the amount of their billings. 
The only "collaborative" aspect of IPL's "aggregation of practices" (as XY put it) was the sharing of the profit pool according to the length of service of equity partners but even this practice had a competitive, individualistic dimension, as XY explained:

Their reputation was reflected in the amount that they billed; each wanting to be "the biggest biller in the place." Even though it didn't make any difference to their formal position in the firm, it was very important to them. The structure in place was supportive of what the individual achieved rather than teamwork.

This highly individualistic and competitive context ensured that no collectively reflexive practices were established. Even the meetings of the National Management Committee, and later the Board, were conducted in formal fashion with no place for dialogue. They were merely intended to provide minimal coordination of multiple individual practices. Supporting the view of Holm (1995, pp. 398-399), this behavior endorses the inherent contradiction between individual and collective interests in organizations; showing that the assumptions and attitudes of IPL attorneys were not conducive to adopting and executing the practices and dispositions that epitomize any form of "collective leadership" (while they could enact "collective resistance" this had no strategic dimension other than "saying no" to any change). In this respect, the abstract power influences upon the nature of their embedded professional practices ensured that the relational and communicative practices required for sophisticated collective "power management" practices, remained undeveloped. Neither XY nor any of the other participants in this transformational drama had any sense of the reflexive practices that could have delivered a critique of existing institutional arrangements; the identification of viable alternatives; and the mobilization of collective reflexive action through which to address the challenges they faced.

In an interview after the transformation, XY lamented:

I was too passive in my attempts to change the situation of the firm. I could see that we were going to be smashed if we continued along the same lines but I don't like confrontation and therefore treaded softly around the issues. Even though we ultimately transformed the structure, the power of a group of resisting equity partners led to WXY having to pay far more than they should have for the business. That has left the firm in a precarious situation today.

While the group favoring change was ultimately able to influence the decision to transform the structure of the firm, the resisting group was able to influence the decision regarding the incentives to be offered for their acquiescence to such change. The honoring of these incentives has left the firm in a precarious social and economic situation. Between the time of the sale of IPL to WXY and the last interview conducted with XY, a third of the non-equity partners had resigned and the share price of WXY had fallen by 58 percent.

\section{Conclusion}

The case reflects the complex power dynamics of organizational change. It shows that what "was going on" during the almost two decades of IPL's transformational journey was inadequate attempts at sense making, scant awareness of the influence of abstract forms of power, and the inappropriate exercise of agentic power leading to disunity and dysfunction in the firm. Nobody demonstrated any awareness of the abstract forms of power that were shaping their perception of the situation and their assumptions about how to address the challenges it posed. Similarly, agentic power was exercised through conventional acts of individual/collective coercive resistance and persistence, without any conception of the need for critical reflexivity at the individual or collective level. In this sense, "what was going on" did not reflect any insight into the power dynamics that were manifesting; nor the presence of any enlightened form of "working with power."

The case raises the issue of the need to understand the growing complexity of the power dynamics that characterize organizational endeavor and change; and how, collectively, to dynamics in organizational change 
"work with" power in all its forms. In this respect, the nature of practices that enable the constructive collective management of the increasingly complex power dynamics that frame institutional domains and organizational life is an area that needs more research. The creation of such critically reflexive practices, however, will be a difficult challenge within organizations, institutions and societies structured to mystify the workings of hegemonic and other forms of abstract power. Herein lies a paradox: one which political naivety is unlikely to manage, in that the demystification of such forms of power begins with the recognition of the politics of human existence and the unwitting acquiescence to disempowerment in many domains thereof. In this respect, sophisticated "working with power" becomes a collective responsibility; one in which attempts are made to make explicit the full range of power dynamics that manifest in any form of collective endeavor. As the case shows, failure to critically scrutinize, and manage constructively, these dynamics leads to outcomes where everyone is worse off.

\section{References}

Adler, P., Kwon, S. and Heckscher, C. (2008), "Professional work: the emergence of collaborative community", Organization Science, Vol. 19 No. 2, pp. 359-376.

Bachrach, P. and Baratz, M. (1962), "Two faces of power", The American Political Science Review, Vol. 56 No. 4, pp. 947-952.

Barley, S. and Tolbert, P. (1997), "Institutionalization and structuration: studying the links between action and institution", Organization Studies, Vol. 18 No. 1, pp. 93-117.

Battilana, J. and Dorado, S. (2010), "Building sustainable hybrid organizations: the case of commercial microfinance organizations", Academy of Management Journal, Vol. 53 No. 6, pp. 1419-1440.

Benson, J. (1977), “Organizations: a dialectic view”, Administrative Science Quarterly, Vol. 22 No. 1, pp. 1-21.

Berger, P. and Pullberg, S. (1965), "Reification and the sociological critique of consciousness", History and Theory, Vol. 4 No. 2, pp. 196-211.

Bertels, S. and Lawrence, T. (2016), "Organizational responses to institutional complexity stemming from emerging logics: the role of individuals", Strategic Organization, Vol. 14 No. 4, pp. 336-372.

Bévort, F. and Suddaby, R. (2016), "Scripting professional identities: how individuals make sense of contradictory professional logics", Journal of Professions and Organization, Vol. 3 No. 1, pp. 17-38.

Borum, F. (2004), "Means-end frames and the politics and myths of organizational fields", Organization Studies, Vol. 25 No. 6, pp. 897-921.

Cardinale, I. (2018), "Beyond constraining and enabling: toward new microfoundations for institutional theory", Academy of Management Review, Vol. 43 No. 1, pp. 132-155.

Carroll, B. and Simpson, B. (2012), "Capturing sociality in the movement between frames: an illustration from leadership development”, Human Relations, Vol. 65 No. 10, pp. 1283-1309.

Clegg, S., Courpasson, D. and Phillips, N. (2006), Power and Organizations, Sage, Thousand Oaks, CA.

Cooper, R. and Burrell, G. (1988), "Modernism, postmodernism and organisational analysis: an introduction", Organisation Studies, Vol. 9 No. 1, pp. 91-112.

Courpasson, D. (2000), "Managerial strategies of domination. Power in soft bureaucracies", Organization Studies, Vol. 21 No. 1, pp. 141-161.

Cunliffe, A. (2009), "Reflexivity, learning and reflective practice", in Armstrong, S. and Fukami, C. (Eds), The SAGE Handbook of Management Learning Education and Development, Sage, London, pp. 405-418.

Foucault, M. (1984), "Space, knowledge and power", in Rabinow, P. (Ed.), The Foucault Reader, Pantheon, New York, NY, pp. 239-256.

Freire, P. (1974), Education for Critical Consciousness, Seabury, New York, NY. 
Giddens, A. (1994), Beyond Left and Right: The Future of Radical Politics, Stanford University Press, Stanford, CA.

Goffman, E. (1974), Frame Analysis: An Essay on the Organization of Experience, Harper \& Row, New York, NY.

Gramsci, A. (1971), in Hoare, Q. and Nowell-Smith, G. (Eds), Selections from the Prison notebooks of Antonio Gramsci, Lawrence \& Wishart, London, pp. 312-819.

Hanlon, G., Dunne, S., Johnsen, C., Shukaitis, S., Spoelstra, S., Stoborod, K. and Weir, K. (2017), "The dark side of management: Gerard Hanlon in dialogue with Ephemera", Ephemera: Theory \& Politics in Organization, Vol. 17 No. 1, pp. 175-188.

Hardy, C. and Clegg, S. (1999), "Some dare call it power", in Clegg, S. and Hardy, C. (Eds), Studying Organization: Theory and Method, Sage, London, pp. 368-387.

Holm, P. (1995), "The dynamics of institutionalization: transformation processes in Norwegian fisheries”, Administrative Science Quarterly, Vol. 40 No. 3, pp. 398-422.

Jameson, F. (1984), "Postmodernism, or the cultural logic of late capitalism", New Left Review, Vol. 147 No. 4, pp. 53-92.

Jepperson, R. (1991), "Institutions, institutional effects, and institutionalism", in Powell, W. and DiMaggio, P. (Eds), The New Institutionalism in Organizational Analysis, University of Chicago Press, Chicago, IL, pp. 143-163.

Kezar, A. (2011), "Grassroots leadership: encounters with power dynamics and oppression", International Journal of Qualitative Studies in Education, Vol. 24 No. 4, pp. 471-500.

Knights, D. and McCabe, D. (1999), "Are there no limits to authority? TQM and organizational power", Organization Studies, Vol. 20 No. 2, pp. 197-224.

Lander, M., Heugens, P. and van Oosterhout, J. (2017), "Drift or alignment? A configurational analysis of law firms ability to combine profitability with professionalism", Journal of Professions and Organization, Vol. 4 No. 2, pp. 123-148.

Lawrence, T., Malhotra, N. and Morris, T. (2012), "Episodic and systemic power in the transformation of professional service firms", Journal of Management Studies, Vol. 49 No. 1, pp. 102-143.

Lawrence, T., Winn, M. and Jennings, P. (2001), "The temporal dynamics of institutionalization", Academy of Management Review, Vol. 26 No. 4, pp. 624-644.

Leicht, K. (2018), "Professions and entrepreneurship in international perspective", in Saks, M. and Muzio, D. (Eds), Professions and Professional Service Firms: Private and Public Sector Enterprises in the Global Economy, Routledge, Abingdon, pp. 9-25.

Lok, J. (2010), "Institutional logics as identity projects", Academy of Management Journal, Vol. 53 No. 6, pp. 1305-1335.

Lukes, S. (2005), Power: A Radical View, 2nd ed., Palgrave Macmillan, Basingstoke.

Mead, G. (1934), Mind, Self and Society, University of Chicago Press, Chicago, IL.

Monbiot, G. (2016), How Did We Get Into This Mess?, Verso, London.

Morrill, C., Zald, M. and Rao, H. (2003), "Covert political conflict in organizations: challenges from below", Annual Review of Sociology, Vol. 29 No. 1, pp. 391-415.

Olakivi, A. and Niska, M. (2017), "Rethinking managerialism in professional work: from competing logics to overlapping discourses", Journal of Professions and Organization, Vol. 4 No. 1, pp. 20-35.

Pache, A. and Santos, F. (2013), "Embedded in hybrid contexts: how individuals in organizations respond to competing institutional logics", Research in the Sociology of Organizations, Vol. 39, Part B, pp. 3-35.

Peck, J. and Tickell, A. (2002), “Neoliberalizing space”, Antipode, Vol. 34 No. 5, pp. 380-403.

Saks, M. and Muzio, D. (Eds) (2018), Professions and Professional Service Firms : Private and Public Sector Enterprises in the Global Economy, Routledge, Abingdon. 
Schilling, A., Werr, A., Gand, S. and Sardas, J. (2012), "Understanding professionals' reactions to strategic change: the role of threatened professional identities", The Service Industries Journal, Vol. 32 No. 8, pp. 1229-1245.

Schostak, J. (2016), "Leaders, leadership and democracy - are they compatible?", Management in Education, Vol. 30 No. 1, pp. 4-9.

Seo, M. and Creed, W. (2002), "Institutional contradictions, Praxis and institutional change: a dialectical perspective", Academy of Management Review, Vol. 27 No. 2, pp. 222-247.

Soulsby, A. and Clark, E. (2013), "Organizational restructuring and change in transition societies: dominant coalitions and the dynamics of managerial power and politics", Competition and Change, Vol. 17 No. 2, pp. 176-196.

Stanley, M. (1978), The Technological Conscience: Survival and Dignity in an Age of Expertise, The Free Press, New York, NY.

Suddaby, R., Greenwood, R. and Wilderom, C. (2008), "Where organization theory and organizational behavior might meet", Journal of Organizational Behavior, Vol. 29 No. 8, pp. 989-994.

Thomas, P. and Hewitt, J. (2011), "Managerial organization and professional autonomy: a discoursebased conceptualization", Organization Studies, Vol. 32 No. 10, pp. 1373-1393.

Thornton, P. and Ocasio, W. (1999), "Institutional logics and the historical contingency of power in organizations: executive succession in the higher education publishing industry, 1958-1990", American Journal of Sociology, Vol. 105 No. 3, pp. 801-843.

Thornton, P., Ocasio, W. and Lounsbury, M. (2012), The Institutional Logics Perspective: A New Approach to Culture, Structure and Process, Oxford University Press, Oxford.

Tilly, C. (1991), "Domination, resistance, compliance ... discourse”, Sociological Forum, Vol. 6 No. 3, pp. 593-602.

Weber, M. (1970), "Power", in Gerth, H. and Wright Mills, C. (Eds), From Max Weber: Essays in Sociology, Routledge, London, pp. 159-264.

Whitehead, P. and Crawshaw, P. (2014), "A tale of two economies: the political and the moral in neoliberalism", The International Journal of Sociology and Social Policy, Vol. 34 Nos 1/2, pp. 19-34.

Williams, R. (1977), Marxism and Literature, Oxford University Press, Oxford.

\section{About the authors}

Emmanuel Mastio is full time Industry Professor in the School of Information, Systems and Modeling at the University of Technology Sydney. His research interests are in organizational studies, particularly in the areas of innovation and change. Before joining academia, he held senior leadership positions in several global industrial organizations.

Kenneth Dovey is Retired Professor with over 40 years of experience in academic roles in South African and Australian universities, leading to professorial appointments in the areas of strategic leadership and leadership for innovation. He continues to engage in research in the area of the leadership practices that facilitate innovation, and to lecture on executive education programs at business schools around the world. Kenneth Dovey is the corresponding author and can be contacted at: kendovey@gmail.com

For instructions on how to order reprints of this article, please visit our website: 